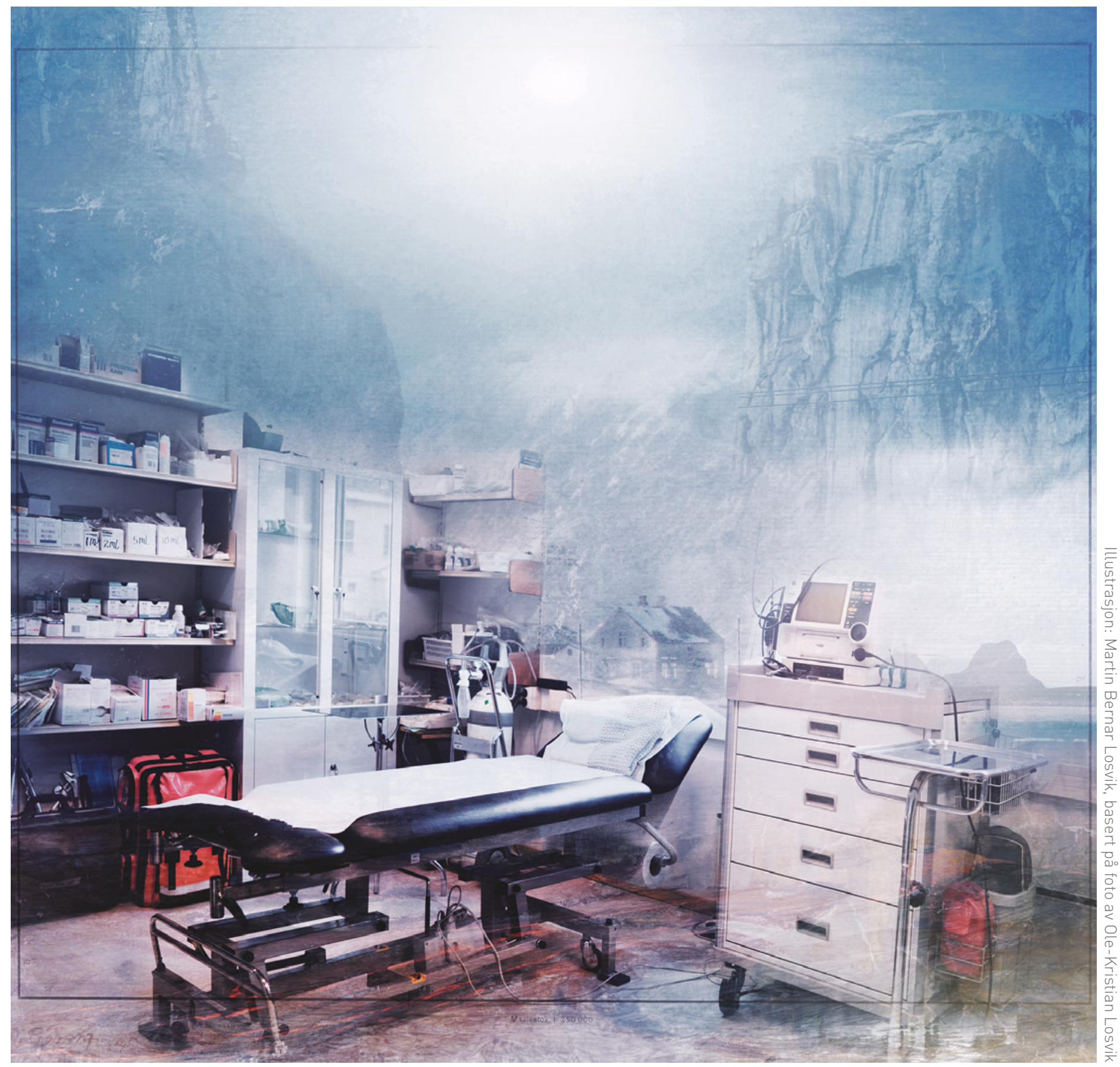

\title{
Røst legekontor
}

(i)

Den ytterste og sørligste kommunen i Lofoten består alene av 365 øyer, men det er kun hovedøya Røstlandet og noen få andre øyer rundt den som er bebodd. Samfunnet lever av fisken i havet rundt øya, store deler av befolkningen på rundt 600 er fiskerfamilier. På Røst finnes det bare én fastlege, og dersom legekontoret er stengt, er det Nordlandssykehuset i Bodø og AMK-sentralen som drifter legevakttelefonen på Røst. 